Metropolitan-Vickers Electrical Co., Ltd. : Dr. C. Dannatt, O.B.E.

Dr. C. DANnatT has been appointed chief electrical engineer of the Metropolitan-Vickers Electrical Co., Ltd., in succession to Mr. G. A. Juhlin, who has resigned, though retaining his connexion with the Company. Dr. Dannatt received his technical educa. tion under Prof. W. M. Thornton at Armstrong College, Newcastle, from which he graduated in electrical engineering in 1921. His studies were interrupted by the First World War. Dr. Dannatt went to Metropolitan-Vickers as a college apprentice in 1921 and afterwards joined the electrical and magnetic section of the Research Departiment, taking charge of the section in 1924. His activities have been mainly concerned with engineering investigations, and he is a recognized authority on electrical measurements especially in relation to magnetism and the behaviour of dielectrics. $\mathrm{He}$ is the principal author of a volume on "Electrical Power Transmission and Interconnection". In 1936 he was awarded the degree of D.Sc. by the University of Durham. Dr. Dannatt was appointed to tho chair of electrical engineering in the University of Birmingham in August 1940; but at the request of the Admiralty he continued part-time activities with the Metropolitan-Vickers Co. ; in the New Year Honours List of 1943 he was awarded the O.B.E. for contributions to naval gunnery. In 1944 he returned to Metropolitan-Vickers as assistant to the chief electrical engineer, and in the following year he was appointed deputy chief electrical engineer.

Mining and Metallurgy at Adelaide: Prof. E. C. R. Spooner

THE Council of the University of Adelaide has appointed Dr. Edgar Clynton Ross Spooner to be professor of mining and metallurgy and director of the Bonython Laboratories at the South Australian School of Mines and Industries, in suecession to Prof. H. W. Gartrell, who died two years ago. Prof. Spooner, who is thirty-nine, was born and received his undergraduate education in Tasmania, and was Tasmanian Rhodes Scholar in 1931. At Oxford he carried out research into electrode potential phenomena, for which he was awarded the degree of doctor of philosophy in 1936, and in 1946 the University of Tasmania conferred on him the degree of doctor of science for further research work in that field. On leaving Oxford, Prof. Spooner was for two years technical assistant to the works director of the National Smelting Company, Avonmouth, and then for seven years technical superintendent and works manager, and later assistant general manager, to the Magnesium Metal Corporation, Ltd., Swansea. Since December 1944 he has been technical adviser to S. G. Warburg and Company and director of research and development to Sutcliffe, Speakman and Company. In 1946 he was a member of the British Industrial Mission which investigated and reported on the active carbon industry of Germany.

\section{Defence Scientific Advisory Committee, Australia}

Ir was announced in Nature of June 28, p. 869, that Mr. A. P. Rowe had been appointed to take charge of a scientific advisory eommittee for defence in Australia. The United Kingdom Government has agreed to loan Mr. Rowe's services for a period of one year to the Australian Government for the purpose. Mr. Rowe will carry out the functions of defence scientific adviser in Australia and will establish a Defence Scientific Advisory Committee of which he will be chairman. The Committee will be constituted as follows: Defence Scientific Adviser, a representative of the Council for Scientific and Industrial Research, and one representative each of the following subjects-physies, chemistry, engineering and medicine; specialist Service and munitions representatives and scientific workers will be co-opted as required. The functions of this Committee will be to maintain a general survey of the scientific field and bring to the notice of the Defence Committee and the Chiefs of Staff Committee or through the Council of Defence to the Government, scientific developments having either direct or indirect bearing upon national defence.

\section{British Hat and Allied Feltmakers Research Association: Dr. Thomas Barr}

Dr. Thomas Barr has been appointed director of research to the British Hat and Allied Feltmakers Research Association. This newly formed Research Association will carry out investigations on problems provided by members of the felt-hat industry. Initially, the work of the Association will be carried out in accommodation provided by the Textile Industries Department of the University of Leeds. The location of the new research group at Leeds should prove an attraction and stimulus, since for the past quarter of a century Leeds has been -one of the most active centres of both fundamental and applied research on animal fibres. Dr. Barr is at present in charge of a research section in the I.C.I. Dyestuffs Division, carrying out fundamental research work on textile processes involving the study of cellulose, natural and regenerated, the modification of wool and physiochemical studies of colloidal electrolytes such as synthetic detergents, etc.

\section{'Sponsored' Research for Industry}

Is his address when opening the Fulmer Research Institute at Stoke Poges on July 2 (see p. 165), Sir Stafford Cripps said that the new Institute, which is eonstituted broadly on lines similar to the Mellon Institute in the United States, may well be the prototype of a kind of research organisation which could largely fill the gap between scientific research and its application in production processes, particularly for the smaller firms. There are, he said, three essential principles in any research institute which seeks to perform this general function for industry : its staff and equipment must be first class ; the results of research sponsored by an individual firm must be retained by that firm, either as patents or as general technique and knowledge; and thirdly, the Institute should not be profit-making. Research and profit-making, he believes, do not mix well together, and although research should be carried out with reasonable economy, and elaborate equipment may not be necessary, it must be allowed ample time and a wide range of experimental failure. All these principles have been adopted in setting up the Fulmer Research Institute, and it has also been arranged for members of the staff of the sponsor firms to go and work in the Institute so as to be in a position to translate the results of the research readily into terms of factory processes. Sir Stafford Cripps also commended the Institute for the economy in scientific effort and said that the Government heartily welcomes this initiative as filling the gap which will be left even when joint research organisations have been set up 